\title{
Colletotrichum plurivorum causes anthracnose on okra in Brazil
}

\author{
Izabel Cristina Alves Batista ${ }^{1}$ (ID $\cdot$ Alessandra de Jesus Boari ${ }^{2} \cdot$ Caterynne Melo Kauffmann $^{3} \cdot$ Katia de Lima Nechet $^{4}$
}

Received: 5 February 2020 / Accepted: 14 July 2020 / Published online: 17 July 2020

(C) Società Italiana di Patologia Vegetale (S.I.Pa.V.) 2020

Keywords Ascomycetes $\cdot$ Fungal pathogen $\cdot$ Vegetable $\cdot$ Abelmoschus esculentus

Okra (Abelmoschus esculentus) is a tropical vegetable cultivated widely in the Amazon region. In August 2016, typical anthracnose symptoms were observed on the leaves of okra in Altamira, Pará, Brazil with $60 \%$ disease incidence. Symptomatic leaf tissue were surface sterilized, rinsed with sterile water, and plated on potato dextrose agar. Colonies had greyish white aerial mycelium in 7-day-old cultures at $25 \pm 2{ }^{\circ} \mathrm{C}$. Conidiophores were smoothwalled, septate. Conidiogenous cells were hyaline, straight, and $19 \times 4 \mu \mathrm{m}$. Appressoria were single, elliptical, and $8.5 \times 6.5 \mu \mathrm{m}$. The conidia were aseptate, cylindrical, with round apex and base, and $13 \times 5 \mu \mathrm{m}$. The isolated fungus was identified as Colletotrichum sp. The isolate was deposited in Culture Collection of Microorganisms (CMAA), Jaguariúna, Brazil (CMAA 1735). The isolate was further identified by sequencing the actin $(A C T)$, chitin synthase $(C H S 1)$, beta-tubulin $(T U B)$ and glyceraldehyde-3-phosphate dehydrogenase $(G A P D H)$ genes (Damm et al. 2019). The sequences were deposited in GenBank (accession Nos. MK495949, MK495952, MK495951 and MK495950) and revealed over 98\% identity with Colletotrichum plurivorum (MG747766, MG600847, MG600984 and MK862223). Reference sequences of C. orchidearum and C. magnum species complexes were used for the alignment and the phylogenetic analyses conducted using Bayesian method clustered the isolate in the clade corresponding to Colletotrichum plurivorum. The pathogenicity of the isolate was confirmed by spraying a suspension of conidia $\left(1 \times 10^{6}\right.$ $\mathrm{mL}^{-1}$ ) on okra cv. Santa Cruz 47 with 4-6 leaves and the control

Izabel Cristina Alves Batista

izabel.batista@ufv.br

1 Universidade Federal de Viçosa, Viçosa, MG, Brazil

2 Embrapa Amazônia Oriental, Belém, PA, Brazil

3 Universidade Federal Rural da Amazônia, Belém, PA, Brazil

4 Embrapa Meio Ambiente, Jaguariúna, SP, Brazil plants were sprayed with distilled water. The plants were maintained in a dew chamber for $24 \mathrm{~h}$ under greenhouse at $27^{\circ} \mathrm{C}$ with a 12-h-light/dark photoperiod. After 5 days, dark brown necrotic lesions were observed on the leaves of okra plants whereas control plants were all symptomless. The fungus was re-isolated, and showed the same morphological characteristics as the inoculated strain, fulfilling Koch's postulates. C. plurivorum has been reported to infect papaya (Sun et al. 2019) and cassava (Liu et al. 2019). To our knowledge, this is the first report of Colletotrichum plurivorum causing anthracnose on okra in Brazil.

Data availability Not applicable.

Code availability Not applicable.

\section{Compliance with ethical standards}

Conflict of interest The authors declare that they have no conflict of interest associated with this publication.

Ethics approval Not applicable.

Consent to participate Not applicable.

Consent for publication Not applicable.

\section{References}

Damm U, Sato T, Alizadeh A, Groenewald JZ, Crous PW (2019) The Colletotrichum dracaenophilum, C. magnum and C. orchidearum species complexes. Stud Mycol 92:1

Liu X, Shi T, Li B, Cai J, Li C, Huang G (2019) Colletotrichum species associated with cassava anthracnose in China. J Phytopathol 167:1-9

Sun YC, Damm U, Huang CJ (2019) Colletotrichum plurivorum, the causal agent of anthracnose fruit rot of papaya in Taiwan. Plant Dis 103(5): 1040

Publisher's note Springer Nature remains neutral with regard to jurisdictional claims in published maps and institutional affiliations. 